Document downloaded from:

http://hdl.handle.net/10251/34994

This paper must be cited as:

Lloret Romero, MN. (2011). Libraries' response to the crisis: measures to mitigate its impact. The Bottom Line: Managing Library Finances. 24(4):236-240. doi:10.1108/08880451111193352.

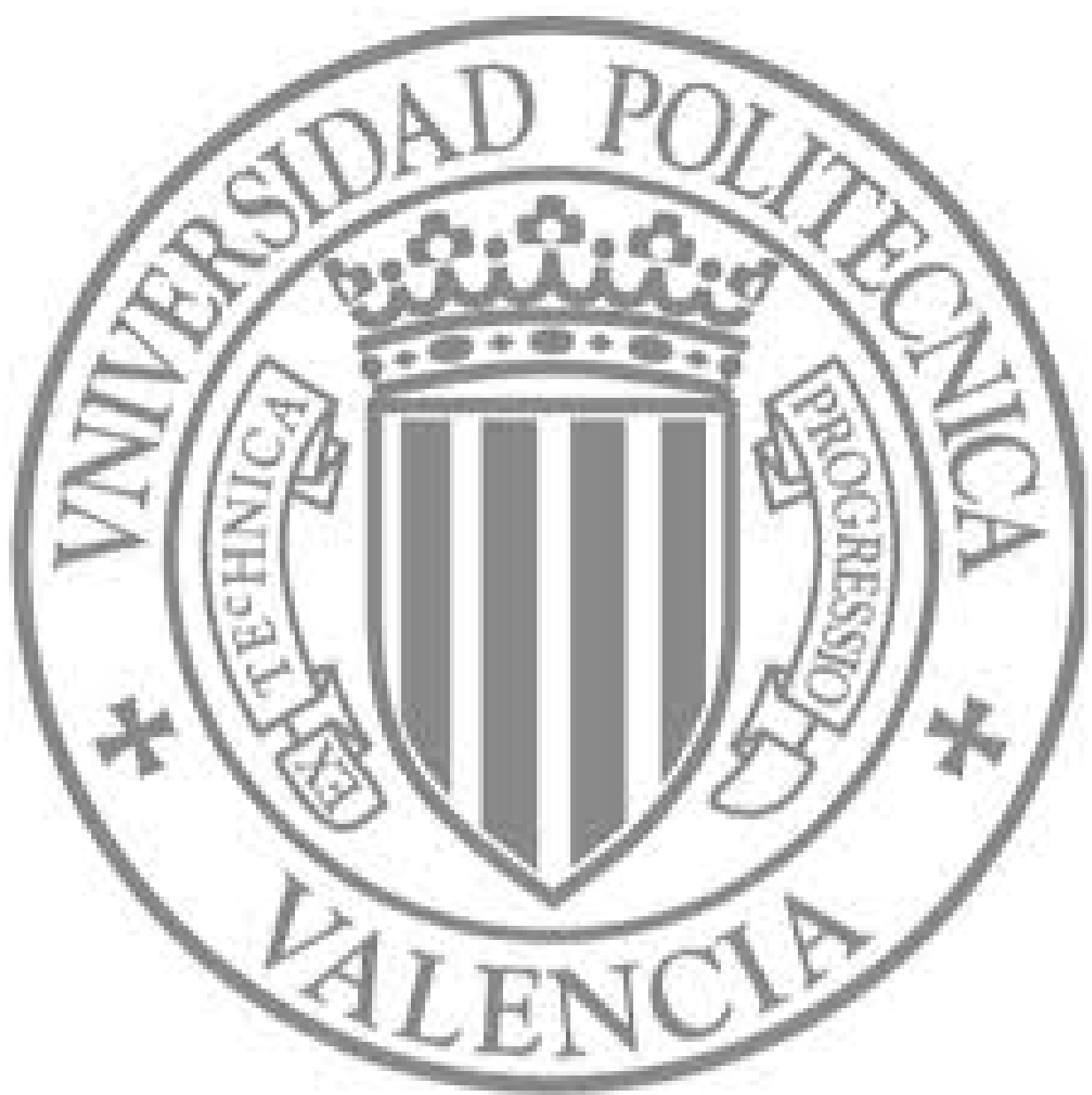

The final publication is available at

http://dx.doi.org/10.1108/08880451111193352

Copyright Emerald 


\author{
Nuria Lloret Romero, Universidad Politécnica de Valencia \\ Valencia, Spain
}

nlloret@upvnet.upv.es

Purpose: The aim of this paper is to present the initiatives that libraries and information services should take from the standpoint of management or services in times of economic crisis or recession such as the one we are currently experiencing. In current times when budget cuts, downsizing and cuts in equipment are continuous, it is important to reflect on the path that each library should take to overcome the crisis while providing users the services they require.

Design/methodology/approach: There are projects internationally, including, inter alia, Pulman and Calimera, which highlight the supportive role of lifelong training, of both formal and informal education and of the libraries 'contribution to social and economic development. They even claim that along with archives and museums, libraries should collaborate in developing a strong local economy by supporting local businesses and industry in different ways (offering information services, stimulating the acquisition of basic skills and providing career guidance).

Logically, the public library is not the only -and may not even be the principal agent or the one most associated with this problem- which can address job insecurity, economic hardship and people's need for training. However, in our view it can have a significant and active role, in coordination with other agents, and it is important to take advantage of its potential: its collections, the training of its staff members, its familiarity with the everyday life of towns and cities, its openness to everyone without any preconditions, etc.

Findings: In recent years some libraries have seen their financial resources reduced, or have remained stagnant in face of an increased demand for service. A first consideration in this context, which might be very hard but is unavoidable when faced with such a reality, is the need to rethink which services to keep and which to reduce or cancel in the event are not enough fund. At times it is necessary to choose what to do without

Originality/value: Public libraries are increasingly becoming more of a social space where all people can go for information, learning and culture, regardless of their age, level, training or background. The library as a resource, which in many cases is public, and which enables individuals to enjoy their right to information should be defended to the fullest in times such as these. Also, to the greatest extent possible, libraries should be used in a compensatory manner, targeting people with fewer resources who are in need of skills that enable them to return to the workplace or reduce the consequences of lack of income. 
Keywords: crisis, financial measures

Paper type: Viewpoint

Accepted: $10^{\text {th }}$ October 2011

The aim of this paper is to present the initiatives that libraries and information services should take from the standpoint of management or services in times of economic crisis or recession such as the one we are currently experiencing.

In current times when budget cuts, downsizing and cuts in equipment are continuous, it is important to reflect on the path that each library should take to overcome the crisis while providing users the services they require.

Especially in times such as these, the function of the library is enhanced due to: the large number of people who are unemployed; users with the need for independent learning resources which help them to improve their job options; or simply the need to create a space for free leisure activities in times when people cannot afford any unnecessary expenditure.

In such times, libraries are redesigned to be more than a place for consultation, strengthening their image as a cultural center and space for social and cultural integration. This is accomplished by promoting multicultural services, providing access to information technologies and networks, serving disadvantaged groups, and so on.

There are projects internationally, including, inter alia, Pulman and Calimera, which highlight the supportive role of lifelong training, of both formal and informal education and of the libraries 'contribution to social and economic development. They even claim that along with archives and museums, libraries should collaborate 
in developing a strong local economy by supporting local businesses and industry in different ways (offering information services, stimulating the acquisition of basic skills and providing career guidance).

Logically, the public library is not the only -and may not even be the principal agent or the one most associated with this problem- which can address job insecurity, economic hardship and people's need for training. However, in our view it can have a significant and active role, in coordination with other agents, and it is important to take advantage of its potential: its collections, the training of its staff members, its familiarity with the everyday life of towns and cities, its openness to everyone without any preconditions, etc.

\section{Crisis and libraries}

Libraries are affected by the crisis in various both direct and indirect ways. The library is indirectly affected because the society is a system in which different elements interact and influence each other. Directly, there are fewer resources and more users requiring services:

- A lower budget for more users

a) People who are unemployed go to libraries because they have more time, and during what used to be their work day they may visit libraries to study and search for information.

b) The number of users will also increase because although they have not lost their jobs, many people begin saving or purchase less books and other cultural products, substituting these purchases with the use of library resources.

c) A decrease in other costly leisure practices such as travel and a general contraction of consumption also results in the use of libraries. 
d) Unemployed individuals who return to the professional or university education system also become potential and actual users of library services.

\section{- A lower budget translates into fewer employees}

a) Fixed costs and particularly, staff costs, account for a significant portion of the library budget, e) In times like these, staff costs are reduced, and more specifically, extra part-time employees and special projects are cut causing services to suffer.

b) The remaining staff is overloaded with tasks previously carried out by employees who no longer work for the library. Given the increase in the workload and decrease in staff, the quality of the services offered is affected.

c) Due to the employees' personal problems or the uncertainty of their jobs, an environment of negativity arises that leads to a lack of interest in work and a lack of the creativity needed to invent new ways of providing services.

\section{How can library services be funded and provided despite budget constraints?}

In recent years some libraries have seen their financial resources reduced, or have remained stagnant in face of an increased demand for service. A first consideration in this context, which might be very hard but is unavoidable when faced with such a reality, is the need to rethink which services to keep and which to reduce or cancel in the event are not enough fund. At times it is necessary to choose what to do without, some examples being as follows:

- Defending the increase in opening hours seems to be essential. It would be a grave setback to have to close at noon or during certain weekend hours after a longer timetable has already been consolidated at libraries in medium or large cities. However, in the event that services have been outsourced, these hours are sometimes 
the first items that have to be reduced.

- Another key issue is timely acquisitions, since otherwise there would be gaps in the collection, which would grow old in relative terms in a time of increased loan demands.

- Some cultural activities might be canceled or reduced where they are offered by other entities in the area and there may be other alternatives. It seems more important, for example, to continue activities which promote reading such as storytelling or reading clubs rather than continuing to hold lecture series for a small minority when there are other bodies that already program a fair number of such activities.

- Another expense that is often questioned is related to promotion, advertising and merchandising, etc., because although it is important it tends to be considered unnecessary in comparison to the provision itself of the service advertised.

-Libraries should seek to the greatest extent possible, to continue contracting monitors, self-employed professionals, and cultural management and printing companies, who make storytelling, animation, workshops and outreach materials, etc. available, because for them libraries are a source of work and if they are terminated along with many others, it will leave them financially inviable. Also, they are an important part of the cultural fabric of our cities and business areas.

However, before tackling these difficult dilemmas, libraries must strive to continue operating and maintain their financial and human resources. For this purpose:

- It is necessary to actively negotiate the budget and demonstrate the social utility of libraries, alongside other publicly funded areas of culture and entertainment,

- seek alliances with other social organizations such as non-profit 
organisations with which objectives can be agreed upon,

- Take into account the possibilities of relying on volunteers to continue offering services to groups which are excluded and at risk of exclusion,

-attempt to benefit from government aid for economic recovery (renovation and improvement of library facilities if so permitted by the E Plan, the provision of laptop computers through bulk purchases for schools, aid for digitilization, etc..) Such aid should be in advance and an attempt should be made to adapt it so libraries can benefit from such aid,

- Seek the help of training and employment agencies in autonomous regions and municipalities, as well as available state aid,

- Check the fundraising (Llueca, 2005), sponsorship or patronage opportunities taken advantage of in other library contexts,

- Seek alliances with users, associations of friends, media, and mediators such as teachers and other social professionals to find the help and support required for the demand and provision of library services.

- Take advantage of the potential of technologies, open and free programs, social networks for information sharing, content management, collaboration with users, promotion and viral marketing.

\section{Conclusions}

Public libraries are increasingly becoming more of a social space where all people can go for information, learning and culture, regardless of their age, level, training or background. The library as a resource, which in many cases is public, and which enables individuals to enjoy their right to information should be defended to the fullest in times such as these. Also, to the greatest extent 
possible, libraries should be used in a compensatory manner, targeting people with fewer resources who are in need of skills that enable them to return to the workplace or reduce the consequences of lack of income.

It is an ideal place to support those who are trying harder than ever to access learning opportunities, benefit from on request career counseling, take training courses in various subjects or take part in programs whose purpose is to strengthen basic skills such as languages, computer literacy, communication, interviewing or CV presentation techniques, and the use of information sources, job searching skills, and so on.

I consider focusing on these tasks and services to be quite consistent with the purposes of libraries and an example of how such libraries adapt to social needs and engage with them.

The result, besides being beneficial to people, could be the extension of a social view of libraries in which their mediating role in lifelong learning is perceived more clearly. The contribution to improving citizens' labour market opportunities and the acquisition of basic, generic or specific skills allies libraries to regional employment and professional training services.

This will help libraries to be seen as continuous learning institutions within the government administration as a whole. Consequently, this may be an opportunity for libraries to actively manage their capacity for creativity and innovation, strengthening their positions so as to defend the budgets required to meet the public's demands.

The crisis will be overcome, and it would be nice if it were to result in citizens who value education and lifelong learning more than material enrichment, and who are more critical, participatory and socially united. Even more splendid would be for the library to be present in this collective imaginary as a resource or a possible guide 
in this change of direction that our world so needs.

\section{References}

Álvarez-Massó, M. "Biblioteca Pública como Centro de Aprendizaje Abierto: abriendo nuevos horizontes en la Red de Bibliotecas Municipales de la provincia de Barcelona”. XI Jornadas Españolas de Documentación, Zaragoza, 20-22 de mayo, 2009. $\square$ http://www.slideshare.net/fcampal/malvarezmassfesbid20ogdef

Balavoine, A. "L'ouverture vers les domaines de l'emploi, de l'insertion et de la formation: retour d'expérience à la médiathèque de saint-quentin-en-yvelines”. Bulletin des Bibliothèques de France, 2009, pp.54-2 $\square$ http://bbf.enssib.fr/consulter/bbf-2009-02-0059$\underline{010}$

Brinkley, J., Lehn, C. “Alphabétisation et lutte contre l'illettrisme en Californie: l'action des bibliothèques". Bulletin des Bibliothèques de France, 2009, pp. 54-2. $\square$ http://bbf.enssib.fr/consulter/bbf2009-02-0035-005

Chourrot, O., Meller-Liron, E. "Bibliothèques et insertion professionnelle". Bulletin des Bibliothèques de France, 2009, pp.542. $\square$ http://bbf.enssib.fr/consulter/bbf-2009-02-0006-001

Coloquio ALCI. Planeación Estratégica: biblioteca en tiempos de crisis. Veracruz, Universidad Autónoma Veracruzana, 23-25 de septiembre de 2009. $\square$ http://www.uv.mx/usbi ver/alciog/

Giappiconi, T, Girard, C. "Mutualiser l'action des bibliothèques territoriales et universitaires: répondre aux enjeux des formations initiale et continue". Bulletin des Bibliothèques de France, 2009, pp.54-2. $\square$ http://bbf.enssib.fr/consulter/bbf-2009-02-0018-003

Las Vergnas, O., Prokhoroff, C. "La cité des métiers de la Villette: un outil d'insertion professionnelle au sein d'une 
bibliothèque”. Bulletin des Bibliothèques de France, 2009, pp. 54$2 \square \underline{\text { http: //bbf.enssib.fr/consulter/bbf-2009-02-0050-008 }}$

Lopez, C., Yon-Cassat, F. "Prisme, au service des demandeurs d'emploi et des créateurs d'entreprise : un pôle de ressources et d'information sur le monde de l'entreprise à la BnF'. Bulletin des Bibliothèques de France, 2009, pp. 542. $\square$ http://bbf.enssib.fr/consulter/bbf-2009-02-0056-009

Llueca, C. "Fundraising: possibilitats I usos en les pràctiques de captació de recursos per a patrocini mecenatge o esponsorització”. Item, 2005, $\quad$ n. $\quad 39, \quad$ pp. 2738. $\square$ http://www.raco.cat/index.php/Item/article/view/22633/40 756

Rooney-Browne, C. "Rising to the challenge: a look at the role of public libraries in times of recession”. Library Review, 2009, v.58, n.5, pp. 341-352.

The State of America's Libraries Report. American Library Asocciation.

2009. $\square$ http://www.ala.org/ala/newspresscenter/mediapresscent er/presskits/2009stateofamericaslibraries/State\%20draft 04.10.0 9.pdf 